wounds, scars, shards of colonialism live on in her grandmother's struggles, in the harsh community's attitudes towards her - both men and women are implicated; in the descriptions of unrelenting conditions of poverty, exploitation, of racism. Yet, good lives are made even of this - lives filled with love, affection, care, bonds, magical stories that conceal and reveal, narratives and a strong spirituality that sustain, a past that both haunts and nourishes, a past and a present that provide a sense of belonging which is precious. Parita Mukta explores the purpose of writing thus: ' $[W]$ riting knowledgeably. Writing words. Words have a way of reaching out, of binding, of opening up different universes: they can also undo, pierce, rive. Words contain that magic which dissolves the boundary between a hard rock and the ether of the inner eye, and the power to scythe through the tinsel wrappings around the world to reveal the house of poverty and the house of arson - look, there, right at the heart of the globe, where genocide takes many forms' ( $p$. 179). This book reveals contradictory and multi-layered realities that are inhabited. Reading and receiving Parita Mukta's memoir is pleasurable, thought provoking, emotional and demanding as it challenges the reader not to reach out for the already thought, because as she herself warns '...unless we are vigilant we will always be tugged by the pull of the known' (p. 184).

\title{
Amal Treacher
}

\section{references}

Hodgkins, K. and Radstone, S. (2003) editors, Contested Pasts, London: Routledge.

Kuhn, A. (1995) Family Secrets: Acts of Memory and Imagination, London: Verso.

Radstone, S. and Hodgkins, K. (2003) editors, Regimes of Memory, London: Routlege.

Warner, M. (1994) From the Beast to the Blonde, London: Chatto and Windus.

doi: $10.1057 /$ palgrave.fr. 9400124

\section{Beyond the frame: feminism and visual culture, Britain 1850-1900}

Deborah Cherry; Routledge, London and New York, 2000, 288 pp, PbK ISBN 0-415-10727-X

This scholarly but accessible book charts the complex relations between feminist politics, women's art practices and new forms of urban life in the 19th century Britain, to explore: 'the sexual politics of vision in the modern city and pictorial perception in a colonial theatre' (p. 1). As this suggests, Deborah Cherry is particularly attentive to the multiple sites in which women were active participants 
and agents in the visual cultures of Victorian England, as well as to the ways in which issues of race and nation, as well as class and gender, were played out within and beyond its shores. She traces the various networks of engagement between art and feminism, artists and activists - often the same women - in the 1850 s and 1860s, demonstrating how the visual was intrinsic to the new mass politics of feminism. Cherry's research is impressive in its detailed empirical analysis, but this is always embedded within strong theoretical frameworks so that, for example, when she maps the particular locations in London that were inhabited by women artists and activists, it is to show how 'space and subjectivity were mutually defining' ( $p$. 24). In a central chapter on the public reception of Harriet Hosmer's sculpture, Zenobia, in 1862, Cherry likewise brings detailed archival research to support her argument that '[a]rt criticism, visual culture, feminism and race were complexly enmeshed in struggles over knowledge and power' (p. 102), in which the issue of women's authority in public life was at stake.

The 'frame' of the title is both that of the discipline of art history, which has ignored the significant contribution of feminism to the making and viewing of the 19 th century British visual culture, and of British society itself, within which most accounts of 'Victorian women artists' have been framed (Cherry, 1993). By drawing on an interdisciplinary field of studies in 'new' art history, urban geography, gender history, postcolonial and critical theory, Cherry deftly tracks the interrelationships between visuality and sexual politics, urban spectacle and feminist networks, imperial visions and female travel, that were part of the complex formation of mid -19 th century feminism. Equally importantly, she shifts her focus beyond the 'frame' of England to explore the significance of colonialism, specifically in Algeria, to the making of forms of feminist (visual) subjectivity. Cherry gives a fascinating account of how Algeria became the favoured tourist destination of radicals and feminists in the 1850 s, offering middle-class women a degree of escape from social convention at home.

The strength of this book is the critical clarity with which Cherry maps the emergent forms of feminist culture and politics in the mid -19 th century as both a radical campaigning movement for middle class women's equality and deeply implicated in the imperialist project of European colonialism. Central to her thesis are two concepts developed by the postcolonial critic, Gayatri Spivak. which provide a theoretical underpinning for crucial aspects of her argument. The first is that of 'the militant female subject' ( $p$. 9) as a new model of female individualism, as much a product of nation and empire as of sexual politics, and who is exemplified by the figure of the woman artist.

Independent, self-motivated and self-aware, women like Barbara Leigh Smith (Bodichon) combined feminist activism - she drafted the 1855 petition to Parliament on married women's property rights - with professional art practice and, at the same time, articulated views about 'native' women who were infused with colonial ideology. Spivak's concept of 'worlding', that is the 
imperialist project of 'texting, textualising, a making into art, a making into an object to be understood' (quoted p. 77), provides Cherry with a means of interpreting the contradictory position of feminist radicals, who maintained an effortless superiority to Arab women in Algeria while simultaneously planning their campaigns on behalf of Englishwomen in London. This comes as a timely reminder that, then as now, feminists do not occupy consistent positions and that feminist and imperialist politics may sometimes form disturbing alliances.

This is a compelling book that wears its scholarship lightly and makes a major addition to the rich feminist literature on the gender, visual culture and urban spectacle in the 19th century London (Nead, 1988, 2000; Walkowitz, 1992). I have two minor caveats, both of which hinge on the misleading nature of the title: this is not an account of feminism and visual culture in Britain, but rather in London the emergence of feminist cultures in the provinces and in Scotland are mentioned only in passing in the final chapter - and while she touches on the figure of the 'New Woman' of the 1890s, it is evident that Cherry's real passion and research lies in the 1850s and 1860s, decades of the emergence and formation of the new subjects and visual cultures of feminism.

\section{Rosemary Betterton}

\section{references}

Cherry, D. (1993) Painting Women: Victorian Women Artists, London \& New York: Routledge.

Nead, L. (1988) Myths of Sexuality: Representations of Women in Victorian Britain, Oxford: Basil Blackwell.

Nead, L. (2000) Victorian Babylon, London and New Haven: Yale University Press.

Walkowitz, J.R. (1992) City of Dreadful Delight: Narratives of Sexual Danger in Late Victorian London, London: Virago.

doi: $10.1057 /$ palgrave.fr. 9400125

\section{Looking back to the future: essays on art, life and death}

Griseida Pollock, introduction and commentary by Penny Florence; G + B Arts International, Amsterdam, 353 pp, 2000, PbK ISBN 90-5701-132-8£16.99

This book is an edited collection of Griseida Pollock 's critical, polemical and theoretical essays from the 1990s, with an introduction and commentary by Penny Florence. It brings together writings that have previously appeared in a number of different publications ranging from the women's art magazine make to the 